\title{
DMFT Study (Decayed, Missing, and Filled Teeth) in HIV Seropositive Patients: Case-Control
}

\author{
Layanne Monaliza Januário de Lima, Priscila Souza da Silva, Érica da Silva Carvalho, Ângela \\ Xavier Monteiro, Andrea Renata do Nascimento Souza, Tirza Almeida da Silva, Clarissa \\ Santana Cruz, Luziane Vitoriano da Costa, Kenne Samara Andrade Martins, Rômulo Chaves \\ Pereira de Oliveira, Eduardo Jorge Sant'Ana Honorato
}

\begin{abstract}
The Human Immunodeficiency Virus has become increasingly common among the population. Infection with the virus affects the T-CD4 lymphocytes, which are the defense lymphocytes of the human body, weakening the immune system and causing the onset of opportunistic diseases. The oral cavity is an essential source of information for the diagnosis and prognosis of diseases associated with HIV / AIDS infection. Objectives: To evaluate the comparison of the DMFT index in patients with HIV who use antiretroviral with patients in the control group. Method: An observational analytical case-control study was conducted in patients diagnosed with HIV infection and patients without diagnosis of infection at the local public clinic in Manaus, Brazil. Results: In the results obtained from the 60 patients evaluated, 30 who had the virus and 30 without the virus. Higher DMFT values were observed in individuals with HIV than in the control group, with an average of 8.94 for patients without HIV and 10.07 for patients with the virus. Conclusion: The DMFT has high indications in patients with HIV+ compared to HIV-, some associations were made as the medications administered and the problematic access of patients to the oral health service
\end{abstract}

Index Terms- Antiretroviral, DMFT, HIV

\section{INTRODUCTION}

Acquired Immunodeficiency Syndrome (AIDS), caused by the etiological agent human immunodeficiency virus (HIV) was discovered in 1983. It was initially identified in the United States in the city of San Francisco and New York in 1981. Reporting occurrence of a type of pneumonia in young male homosexuals associated with cellular immunodepression ${ }^{1,2}$.

This retrovirus is believed to have originated from the African continent. Infection with the virus affects T-CD4 lymphocytes, which are the defense lymphocytes of the human organism, weakening the immune system and causing opportunistic diseases that indicate $\mathrm{HIV}^{2}$

Technological advances and better knowledge of the etiopathogenesis of AIDS have allowed the emergence of new

Layanne Monaliza Januário de Lima, School of Health, UNINORTE Priscila Souza da Silva, School of Health, UNINORTE

Érica da Silva Carvalho, School of Health, UEA

Ângela Xavier Monteiro, School of Health, UEA

Andrea Renata do Nascimento Souza, School of Health, UNINORTE

Tirza Almeida da Silva, Psychology Department, UNIP

Clarissa Santana Cruz, School of Health, UEA

Luziane Vitoriano da Costa, Psychology Department, UNIP

Kenne Samara Andrade Martins, Psychology Department, UNIP

Rômulo Chaves Pereira de Oliveira, School of Health, UFAM

Eduardo Jorge Sant'Ana Honorato, School of Health, UEA proposals for diagnostic, prophylactic, and therapeutic interventions, which can be attributed to the significant increase in patient survival ${ }^{3}$. The diagnosis of HIV infection is in the detection of anti-HIV antibodies. The most used tests for the diagnosis of infection are ELISA, rapid test, and Western Blot, but the last one is not widely used in Brazil because of its high cost ${ }^{4}$.

Kleine Palmer developed the DMFT index in 1937 with modifications over the following decades. THE DMFT is evaluated in decayed, missing, and filled teeth. The oral cavity is an essential source of information for the diagnosis and prognosis of the disease associated with HIV infection and DMFT. We can also verify the relationship of the indices in seropositive patients, due to the high consumption of sucrose due to ingested medications and other factors coming from the virus compared to a group of patients who are not positive for HIV. Since it is beneficial to use simplified indexes for this type of study, ${ }^{5.1}$

Epidemiological surveys must be frequent to control DMFT indexes and support dental strategies6. In developed countries, the prevalence of caries has declined in the last three decades in the twentieth century and the early twenty-first century ${ }^{8}$.

The prevention and social measures program aimed at addressing social exclusion and public health interventions for the most vulnerable groups in the field of oral health promotion is focused on heterosexuals, where the Brazilian epidemy is not concentrated, but there has also been discussion about the development of the epidemic ${ }^{7}$.

The aim of this study was to evaluate and compare the DMFT index in HIV-positive patients and the control group.

\section{METHOD}

This study was submitted to the Ethics and Research Committee with CAAE: 45587815.8.0000.5016 and approved.

Study Model

An observational analytical case-control study.

Reference Population

Patients treated at the local public clinic- (Specialized Assistance Service in HIV / AIDS).

Study Population

Group 1 - Patients treated at the clinic with a diagnosis of HIV / AIDS infection.

Group 2 - Patient treated at the same clinic without diagnosis of HIV / AIDS infection. 


\section{Eligibility Criteria}

Group 1 (cases) - patients diagnosed with HIV / AIDS infection, of both genders and over 18 years of age, followed up at the clinic

Group 2 (Controls) - patients without HIV infection, followed up in the

clinic, both genders and over 18 years.

\section{Ineligibility Criteria}

Patients who, besides being positive for HIV, were diagnosed with systemic diseases such as diabetes, cancer, autoimmune diseases or drug abuse.

\section{Patient Recruitment}

The statistical sample of the thesis was analyzed and determined by the tropical statistic $\mathrm{N}=148$ for HIV+ and $\mathrm{N}=$ 148 for the control group. This work was extracted from a pilot project where $\mathrm{N}$ corresponds to the number of patients evaluated in one month.

Patients who meet the inclusion criteria were invited to participate in the study. Those who accepted received information about the study and signed the free and informed consent form

A clinical form with patient identification data and the DMFT dental examination was also completed.

\section{Dental examination}

A complete dental examination was performed, with examination of the oral cavity and teeth. Patients participating in the research were examined for dental caries disease.

The index used is recommended by WHO and is included in its epidemiological survey form. For this exam we used oral flat mirror number 5 , clinical probe.

\section{RESULTS}

The sample of this study consisted of 60 individuals, 30 $\mathrm{HIV}+$, and $30 \mathrm{HIV}$-.

Table I lists the results of the DMFT and components of individuals with Human Immunodeficiency Syndrome and HIV-, according to gender. Higher DMFT value was observed in individuals $\mathrm{HIV}+$ than in case-control individuals. Both HIV+ and HIV- individuals, showed high expressiveness of the caries-lost component than carious and restored components, and the HIV-positive group showed no caries-free individuals.

Table I- DMFT and components of individuals HIV+ and HIV- examined according to gender, Manaus, AM, 2016.

\section{DISCUSSION}

The HIV virus can lead the patient to acquired immunodeficiency and, consequently, depression of the immune system due to decreased TCD4 lymphocytes leading to several oral manifestations, among them the high index of caries ${ }^{8}$.

The problems found for the elaboration of this study and that need to be highlighted are the problematic access of patients with HIV to obtain dental care when they reveal their status to professionals or when they present clinical signs of the disease ${ }^{9}$.
Early oral clinical signs are essential to indicate the stage of HIV and immunosuppressants. Through the use of HA-ART some oral manifestations have decreased, suggesting that it may be the efficacy of the drug and the immune status ${ }^{10}$.

Treatment with antiretrovirals gives a very significant result, but infection remains a global health problem and without origin $^{11,12}$.

The previous treatment of the disease through early diagnosis is extremely important. However, many difficulties still arise during the administration of medication, when the schedule and lack of free medications and in the development of the patient's skills to cope with the complex and challenging to adapt therapeutic regimen ${ }^{13,14}$.

The DMFT has been widely used in epidemiological surveys to measure and compare the experience of dental caries in populations ${ }^{15}$.

This study was an observational study evaluating the oral cavity in HIV+ patients. The main focus of the study was the DMFT index in comparison to serum-negative patients.

Sixty individuals were evaluated. $30 \mathrm{HIV}+$ and $30 \mathrm{HIV}$ case controls, among the HIV+ $70 \%$ were Men and $30 \%$ Women with average of DMFT 10.03 being 1.97 (decayed), 6.10 (missing), 2.00 ( $80 \%$ Women and 20\% Men with DMFT averages 8.94, being 1.3 (decayed), 5.07 (missing), 2.57 (filled).

In Brazil, few studies have reported the experience of dental caries in people living with HIV / AIDS, and most of them were related to children. Tooth decay is known to be an infectious disease, and the various side effects of antiretroviral therapy may contribute to poor oral hygiene and diet, so HIV infection appears to function as a risk factor for caries. Socially appropriate health programs should be guided by the implementation of health programming actions and coordinates and the challenge of continuing to instigate oral health studies ${ }^{16,17}$.

This can be observed from the oral health results of this research, as well as others conducted with people living with HIV / AIDS, that high rates of DMFT were reported ${ }^{18}$.

A survey of women shows that the prevalence of coronary caries is 1-2 times higher among women with HIV + compared to women with HIV ${ }^{19}$

Every individual will be susceptible to dental caries only by preventing it by taking care of the factors of diet, microorganism, saliva, and dental element ${ }^{20 .}$

Taking into consideration the analysis of 7 antiretrovirals determining the ph and sugar content by the thin-layer chromatography method (TCL), it presented $28 \%$ sucrose in the drug Zidovudine AZT, being the most prescribed formula for HIV positive patients allowing a high level of caries ${ }^{21 .}$

\begin{tabular}{cccccc}
\hline & $\begin{array}{c}\text { DMFT } \\
\text { (average) }\end{array}$ & $\begin{array}{l}\text { Decayed } \\
\text { (avg) }\end{array}$ & $\begin{array}{l}\text { Missing } \\
\text { (average) }\end{array}$ & $\begin{array}{l}\text { Filled } \\
\text { (average) }\end{array}$ & $\begin{array}{c}\text { Caries-F } \\
\text { ree } \\
(\%)\end{array}$ \\
\hline Male & 12,17 & 1 & HIV- & \\
Fem & 8,13 & 1,38 & 4,21 & 2,54 & 8,33 \\
\hline Total & 8,94 & 1,3 & 5,07 & 2,57 & 6,67 \\
\hline & & \multicolumn{5}{c}{ HIV+ } \\
Male & 10,14 & 2,33 & 5,86 & 1,95 & 0,00 \\
Fem & 9,89 & 1,11 & 6,67 & 2,11 & 0,00 \\
\hline Total & 10,07 & 1,97 & 6,10 & 2,00 & 0,00 \\
\hline
\end{tabular}




\section{CONCLUSION}

From the research, it was possible to evaluate the DMFT in $\mathrm{HIV}+$ patients, where it is higher compared to the control group patients, taking into consideration the high sucrose level medications and the difficult access of the patients to the dental service. According to the high rate of DMFT in HIV+ patients, it is concluded that dental surgeon follow-up is necessary to improve their oral health and quality of life.

\section{REFERENCES}

[1] Brasil. Ministério da Saúde. Secretaria de Vigilância em Saúde. Programa Nacional de DST e AIDS. -3. Ed. Ver. E ampl. - Brasília: Ministério da Saúde, 2005

[2] Diniz EMA, Vaz FAC, Síndrome da Imunodeficiência adquirida em população de alto risco para doenças sexualmente transmissíveis parte I- Epidemia. Pediatria (São Paulo),1996;18(1):12- 3

[3] Brito AM. A Epidemia de AIDS em Pernambuco: Sobrevida dos doentes no período de 1983 a 1995. Recife, PE 1997.

[4] Corrêa EMC, Andrade ED. Tratamento odontológico em pacientes HIV/AIDS. Revista Odonto Ciência- Fac.Odonto/PUCRS, 2005;20(49).

[5] Cypriano, S. Souza, MLR. Wada, R.S. Avaliação de índices CPOD simplificados em levanta- mentos epidemiológicos de cárie dentária; Revista Pública 2005;39(2): 285-92.

[6] Nascimento S. Scabar LF. Levantamento epidemiológico de carie, utilizando os índices CPOD, cod e IHOS, nos índios da aldeia WAKRI no estado do Para. Rev Inst Cienc Saúde. 2008;246-53.

[7] Narvai PC, Frazao P, Roncalli AG, Antunes JLF. Carie dentaria no Brasil: Declínio, polariza- ção, iniquidade e exclusão social. 2006;19(6):385-93.

[8] Barbosa, LM e Sawyer, D.O. AIDS: a vulnerabilidade social e a evolução da epidemia nos municípios das regiões Nordeste e Sudeste do Brasil* R. bras. Est. Pop., Campinas, v. 20, n. 2, p. 241-257, jul./dez. 2003

[9] Aleixo RQ. Índice CPOD e prevalência de lesões bucais associadas à infecção pelo HIV: Estudo transversal no serviço ambulatorial especializado de Porto Velho-RO. 2008.

[10] Discacciati JAC, Vilaça EL. Atendimento odontológico ao portador do HIV: medo, precon- ceito e ética profissional. Rev Panam Salud Publica/Pan Am J Public Health 9(4), 2001.

[11] Tinós AMFG; Peres SHCS. Xerostomia relacionada a infecção pelo HIV-AIDS: uma revisão crítica. Rev Odontol UNESP. 2014 May-June; 43(3): 214-222.

[12] Araújo, KL. Justino, G. R. Q. NORÕES, E. M. A. T. DIÓGENES, V. C. N. Relação entre indicie de cárie e doenças periodontais em crianças portadoras de HIV; Revista Interfaces, saúde, humanas e tecnologia vol3 (8), pp. 01-06, 26 de Dezembro de 2015.

[13] Kreuger, MRO. Diegoli, NM. Pedrini, RD. Chaves, B. Forlin, DC: Influência da Terapia Antirretroviral nas manifestações orais de pacientes HIV+AIDS; FOL Faculdade de Odontologia de Lins / AIDS (2011).

[14] Brito AM, Castilho EA, Szwarcwald CL. AIDS e infecção pelo HIV no Brasil: uma epidemia multifacetada Rev Sociedade Brasileira de Medicina Tropical 34(2): 207-217, mar-abr, 2000.

[15] Bonolo PF, Gomes RRFM, Guimaraes MDC. Adesão a Terapia Antirretroviral (HIV-AIDS): Fatores associados e medidas de adesão. Epidêmiol. Sev. Saúde v.16 n.4 Basilia dez. 2007.

[16] Aleixo RQ. Scherma AP, Guimaraes G, Cortelli JR, Cortelli SC. DMFT index and oral mucosal lesion associated with HIV infection: cross-sectional study in Porto Velho, Amazoian region-Brasil 2009.

[17] Frias AC, Antunes JLF, Junqueira SR, Narvai PC. Determinantes Individuais e contextuais da Prevalência de carie dentaria não tratada no Brasil. Rev Panam Salud Publica/Pan Am J Public Health 22(4), 2007.

[18] Brasil. Ministério da saúde. Departamento de Análise de situação de Saúde. Saúde Brasil 2008: 20 anos de Sistema de Saúde (SUS) no Brasil/Ministério da Saúde, secretaria de Vigilância em saúde, departamento de Análise de Situação em Saúde. Brasília : Ministério da Saúde, 2009

[19] Phelan JA, Mulligan R, Nelson E, Brunelle J, Alves ME, Navazesh M, Greenspan D. Dental caries in HIV-seropositive women. J Dent Res. 2004;83(11):869-73.

[20] Lima, JEO, Carie Dentaria: Um novo conceito. R Dental Press Ortodon Ortop Facial. Ma- ringá, 2007;12(6):119-130.
[21] Pomarico, L; Czauski, G; Portela, MB;Souza IPR; Kneipp, L; Cariogenic and erosive poten- tial of the medication used by HIV infected children: $\mathrm{Ph}$ and sugar concentration. Community Dent Health, v. 25, n. 3, p. 170-172, Sept, 2008. 